\title{
Developing Strategies Based on Swot Analysis for SMEs
}

\author{
Arlina Nurbaity Lubis ${ }^{1}$, Marhayanie ${ }^{2}$ and Beby Kendida Hasibuan ${ }^{3}$ \\ $\left\{\underline{\operatorname{arlina} @ \text { usu.ac.id }}{ }^{1}\right.$ \}
}

Faculty of Economic and Business, Universitas Sumatera Utara, Medan, Indonesia

\begin{abstract}
Indonesia has so many of cultural heritage. In North Sumatera, there were many of traditional heritage in form of woven. The term of Batik had been widely known to society but Batik was not the only traditional woven from Indonesia. North Sumatera has Ulos, Uis Karo, and Gorga as the local's traditional woven. However, many of the craftsmen were shut down the business as the competition increases. This study evaluate the SWOT analysis to help traditional woven industry in Medan. It was used to formulate a strategic planning to improve business's competitiveness. Focus group discussion were conducted in Samosir and Medan. The result indicated that less cratsmen and business owner adopted SWOT Analysis while running their business. Most of them had no knowledge how to do strategic planning to improve competitiveness. Thus, it is important to help these industries to adopt with the change to perserve traditional heritage.
\end{abstract}

Keywords: Strategic Planning, Internal-external analysis, Ulos, Uis Karo, Gorga

\section{Introduction}

Republic of Indonesia is rich of cultural heritage. In 2009 UNESCO Inagurated Batik as one of heritage of humanity from Indonesia. Many of people believed that Indonesia's Batik was only from Javanese cultural heritage. However that was not the case. Batik can be classified as one of traditional woven clothing from Indonesia. Magdalena et al. (2018) stated that Indonesia's traditional woven fabric was found not only from Java, but also from other area like Sumatera, Kalimantan, Java, and Nusa Tenggara. The most famous traditional fabric of Indonesia was Batik (Java). However, the depth pf Indonesia's cultural heritage was not limited only to Batik. North Sumatera has Ulos, Gorga, and Uis as local heritage. Songket can be found from West Sumatera, Tenun Doyo from East Kalimantan (Khan, 1991; Widiawati and Rosandini, 2012)

As one of traditional heritage, it is important to preserve traditional woven in the future. In North Sumatera, many of the traditional woven was used in traditional festival or cultural activities. The motives often present their unique characteristics. It require creativity to promote and preserve local cultural heritage in modern age (Hartanti, 2011). Many of craftsmen focused on learning how to produce a better quality of woven or clothing based on modern technologies. Most of time the traditional woven only related to cultural activities without adoption toward modern activities (Raizman, 2003). It is argued as the downfall for traditional heritage (Bertalya, 2014).

There were less traditional woven craftsman each year. One of the reason whereas many of people avoid to preserve traditional woven was the business itself. People argued that traditional woven would be hard to challenge modern clothing. Many of them also argued that it was not easy to learn the traditional woven such as Ulos, but the return was less expected. Many more jobs were available with easier to do and a better return. 
As we identified the root problem to improve people's willingness to inhert traditional woven business, the need to improve its competitiveness become essential. To reach competitiveness, the business have to build their own formulate to run the business. Yet many of traditional craftsmen do not formulate their strategy to run the business. Most of them let the flow brought their business.

Most of strategies were formulated based on internal and external business analysis. One of the most common strategic planning tools that used to evaluate internal and external capabilities was SWOT analysis, the Strength, Weaknesses, Opportunity, and Threat (Osita et al. 2014). The first step in strategic planning to achieve competitiveness was to identify and evaluate the strategic factors, the SWOT, and help organization to realize their full potential (Houben, 1999). The strategic management oftenly used to establish long-term activities of the business (Yuksel and Dagdeviren, 2007).

This study aimed to evaluate the application of SWOT analysis in traditional woven industry in Medan. The study focused on mapping the SWOT analysis within industry to identify their strength, weakness, opportunity, and threat in the modern market.

\section{Literature Review}

\subsection{Traditional woven in North Sumatera}

\subsubsection{Ulos}

Ulos, in language means blankets, blankets that warm the body and protect themselves from cold air. The Batak people believe that there are three sources of warmth for humans, namely Sun, Fire, and Ulos. Ulos is considered a source of warmth that is comfortable and familiar with human daily life.

The art of weaving Ulos is inherited from generation to generation, especially to the Batak people. Many traditional activities were carried out using Ulos cloth. The variety and style of Ulos itself has its own meaning for society. The process of making Ulos generally uses looms instead of machines. However, along with the development of technology, Ulos print motifs have now begun. The meaning of Ulos began to shift from weaving to motif.

Ulos is a symbol of warmth for the Batak people. Although at first this meaning came from the need for warmth to protect from the cold temperatures of the mountains which are now no longer widely used, the meaning of Ulos as a symbol of warmth is still held by the community. The warmth grows into a strong sense of kinship attached to the community.

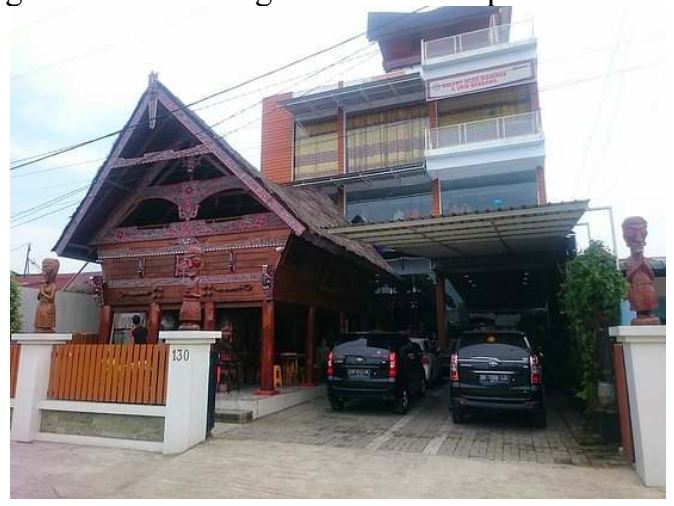


Figure 1. Ulos Galery

Ulos cloth is now being developed by craftsmen, not only limited to the shawl cloth used in traditional events, but has been widely used as a basic material for clothing, laptop bags, tablecloths, and so on.

\subsubsection{Batik Gorga}

Gorga Batak Toba is carved or chiseled art which is usually found on the exterior (exterior) of traditional Toba Batak houses and art tools (drums, cymbals, lutes), and so on. Gorga is a sculpture or painting that is used by using three basic colors that are characteristic of Batak, namely Black, White and Red.

Gorga Batik is a work by displaying various carvings on cloth. The manufacturing process is generally combined with the handwriting method, while colors use natural colors. Even so, now a lot of gorga batik circulating in the market is printed by using a stamp. It was usually using the colors Red, Black and White. These three types of colors are called Sitiga Bolit. The three colors also have special meaning and symbolism according to Batak religious beliefs, namely:

1. White as a symbol of purity, truth, honesty and sincerity.

2. Red as a symbol of strength and courage.

3. Black as a symbol of the authority and leadership

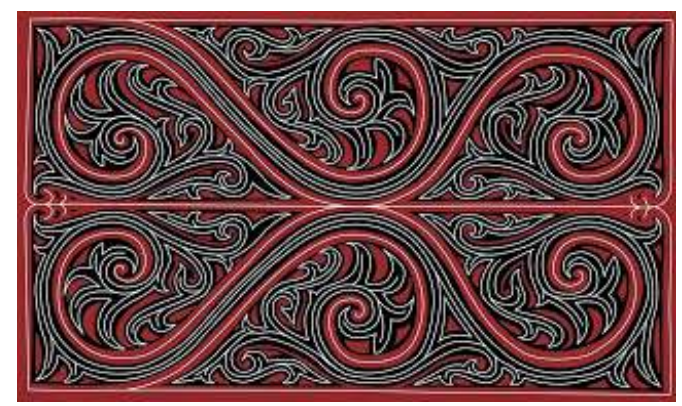

Figure 2. One of Gorga

\subsubsection{Uis Karo}

The traditional Karo traditional cloth (Uis Karo) is a traditional dress used in Karo tribal cultural activities as well as in everyday life. Uis Karo has colors and motifs related to its use or with the implementation of cultural activities.

Uis Karo is made of cotton material, spun and woven manually and uses natural dyes (not using manufacturer chemicals). But there are also some of them using fabric fabrication that is dyed (colored) with natural dyes and made into Karo custom cloth. Some of the Karo Adat Uis are already scarce because they are no longer used in everyday life, or are only used in cultural ritual activities that are related to animistic beliefs and are not being done anymore.

In general, Karo traditional clothing can be divided into three groups, namely: daily wear, clothes for parties, and traditional clothes. The clothes that are commonly used by men are clothes with long-sleeved Chinese scissors, headgear called tengkuluk or bulang and sarong, 
while for women consists of round neck kebaya, sarong (abit), headgear (tudung), and custom cloth named Uis Gara is slung.

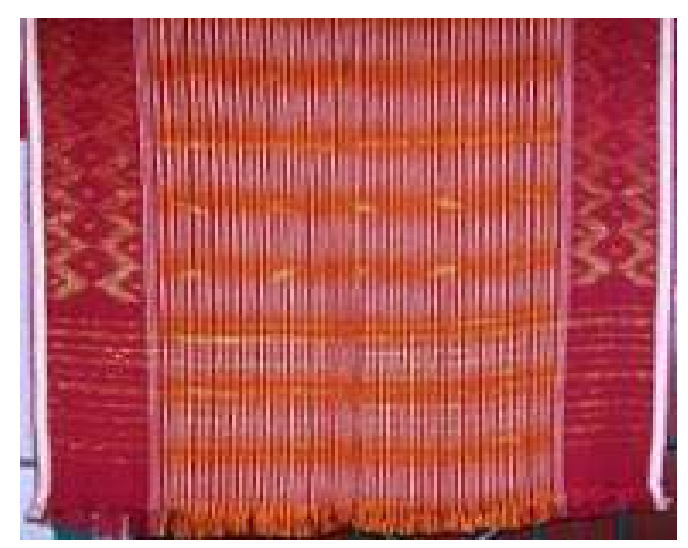

Figure 3. One of Uis Karo

Festival clothes are almost the same as everyday clothes. However, festival clothes are cleaner or new and worn properly, so that they look more polite. Traditional clothing consists of clothing with complete accessories and is used only at parties, such as weddings, entering new homes, death ceremonies, and art parties.

\subsection{SWOT Analysis}

SWOT analysis is a business analysis method that can be used by every business entity in determining the steps to be taken in the future to achieve maximum business growth. Although called the term analysis, SWOT analysis is not an analysis, but the process of identifying the internal and external conditions of the company. Rangkuti (2011) states that the results of the SWOT analysis are conditions of strengths, weaknesses, opportunities, and threats of the company. This list is then re-analyzed to develop an optimal strategy in the future.

\section{Research Method}

\subsection{Research time}

The study was conducted in Medan from April to August 2018.

\subsection{Participant}

In order to understand the external and internal analysis of traditional woven industry in North Sumatera, the research were conducted in Samosir Island and Medan. Both places were chosen as they had the highest density of traditional woven craftsmen and market. A number 
of 20 craftsmen were participated in our focus group discussion for each area, Medan and Samosir Island.

\subsection{Data collection method}

As the reseachers were not directly involved in traditional woven industry, we conducted focus group discussion with the craftsmen and owners. We invited the craftsmen and owners to share their opinion and situation in the emerging market. A structured group discussion were conducted to achieve our objectives. A shared opinion were used as based of our analysis.

\subsection{Data analysis method}

The data were analyzed based on their perspectives and condition of the current market. The strength, weakness, opportunity, and threat were measured based on their problem and activities.

\section{Result And Discussion}

\subsection{Strengths}

The FGD activities held in Medan and Samosir identified that the strength of traditional fabrics in Medan lies in their unique patterns and work processes which generally use traditional methods. Market demand for traditional North Sumatra cloth products is relatively lower than demand for similar fabrics, especially in the marketing area outside North Sumatra, but many requests are present along with the high level of traditional cloth usage at customary events.

Craftsmen learn a lot from experience in improving product quality. Craftsmen are aware of the context of using color-based materials to create products that are better than others. For example, the raw material in the provision of red is better supplied from China, while the green color is better imported from India. This learning process provides an indication that businesses are accustomed to developing higher quality products.

In terms of price, many businesses feel that they can provide more competitive prices compared to their competitors. They stated that it could provide a production cost cut through cheaper labor wages compared to competitors. In this case, workers are given direct training by business owners so that they can cut the cost of training workers which significantly cuts production costs. As a result, the cost of production becomes lower and can provide more competitive prices.

\subsection{Weaknesses}

In general, traditional woven craftsmen in North Sumatra do not conduct market research in the development of their products. Many business people feel the loss due to producing traditional fabrics because the style is not in demand by buyers. For example, people today 
prefer small motifs rather than big motives. Many craftsmen still produce large motifs without regard to market changes. As a result, products are no longer attractive in the market.

Traditional fabric craftsmen rarely have business centers or business groups, especially in Medan. Therefore, they do not have the means to share requests and knowledge in developing the competitiveness of themselves and groups. Relations between craftsmen themselves are often as opposed to one another.

Business actors state that there is no clear management or business management in the operation of the business. Work standards are not owned. Work can be done as long as it can produce and sell the products offered. The obscurity of this procedure brings the problem of negligence in human resources, such as mistakes in using color and so on.

In general, business actors do not have clear contractual ties between employers and workers.

The nature of workers in traditional fabric businesses is more directed to casual workers. This position makes often inconsistent work results for MSMEs. Many workers decide to switch to another business or open their own business after having sufficient capital or getting a better offer from similar businesses.

\subsection{Opportunities}

Business actors stated that they had participated in a variety of SME product exhibition activities both held by local parties and the provincial government. Unfortunately, this opportunity is not widely used by businesses in building relational relationships with other parties. The mindset of business people still leads to "how can I sell this product" and has not been able to optimize the potential for cooperation.

One of the opportunities of business development that can be utilized by Traditional Cloth MSMEs is to establish cooperation with other parties, such as being a sponsor of an event and becoming a superior product of the event; attracting consumer attention based on product exhibits that are developed towards broader business relations; market products to a wider market.

The development of market tastes and product innovation has developed. Traditional fabrics are not only sought after as a traditional event but can be used in a variety of other products, such as clothes, veils, shoes, laptop bags, tablecloths, and so on. This product innovation provides a huge opportunity for businesses to develop their business. When they are unable to produce derivative products, they can establish relationships with tailors, for example. Unfortunately, this practice has not been implemented by businesses. Previously they had tried but were unsuccessful because of other elements which resulted in the inconsistency of the collaboration.

\subsection{Threats}

Many craftsmen consider that the presence of technology is a threat to the sustainability of their business. The presence of printing machines can replace three times the human power. One printing machine is able to provide work equal to the work of three workers. In addition, the work of the engine is more efficient because errors can be minimized. The main problem of the presence of this technology is the relatively high price for business people. The inability to buy the technology means that business competitiveness will be lower than other competitors.

Industry 4.0 by using technology-based revolutions is still not well received by many traditional fabric entrepreneurs. In general, they still use direct interaction with buyers, in the 
sense that buyers visit the store and transactions occur. Only a small percentage of businesses have made online stores to market their products. Many of them are not familiar with the technology. The government has prepared digital MSMEs as a means to connect the gap between the ability of business actors and business digitalization. Unfortunately, business people assess the program provided is too complicated so that for them it is difficult to involve themselves in the digital MSME program.

\section{Conclusion And Recommendation}

Based on our focus group discussion, there were almost no internal-external analysis, the SWOT Analysis conducted by craftsmen and business owners. The current practice from craftsmen and business owners showed that they did the business as the time called. Still, we should be proud to our craftsmen and business owners that they started to creatively adopt traditional woven into modern clothing. They started to creatively develop a new design by mixing the traditional and modern.

As most of the craftsmen and business owners had no theoretical knowledge based on strategic planning, there should be learning center or community services from academia to guide our crafstmen and business owner to adopt SWOT analysis and strategic formulation. The main purpose of this SWOT analysis is to improve their competitiveness, sustainable growth, and perserve traditional woven in the future

\section{Acknowledgments}

The authors gratefully acknowledge that the present research is supported by Ministry of Research and Higher Education. The support is under the research grant PDUPT for year 2018

\section{References}

Bertalya, B., Prihandoko, P., Oktavina, R., Ramadhan, D.S. (2014). Designing a Prototype of Digital Museum to Promote Woven Songket, A Local Product of Sumatera, Indonesia. Jurnal Teknologi, 67, $77-80$

Hartanti, G. Tenun Dan Penerapannya pada Desain Interior sebagai Warisan Budaya yang Memiliki Nilai Jual yang Tinggi. Humaniora, 2(1), 572-582.

Houben, G., Lenie, K., Vanhoof, K., A. 1999. Knowledge-based SWOT-analysis system as an instrument for strategic planning in small and medium sized enterprises, Decision Support Systems, $26,125-135$

Khan, M.B. (1991). Woven Messages: Indonesian Textile Tradition in Course of Time. Hildesheim: Roemer-Museum

Magdalena, L., Suman, A., Setyowati, E., Hakim, L. (2018). Strengthening and Enhancing Product Competitiveness of Dayaks Woven Fabric: Lesson Learned from Ensaid Panjang, Sintang, West Kalimantan. IOSR Journal of Business and Management, 20(2), 68-74

Osita, I.C., Onyebuchi, I., Justina, N. 2014. Organization's stability and productivity: the role of SWOT analysis an acronym for strength, weakness, opportunities and threat. International Journal of Innovative and Applied Research, 2(9), 23-32

Raizman, D. (2003). History of modern design: Graphics and products since the industrial revolution. Laurence King Publishing 
Rangkuti, F. (2011). SWOT Balanced Scorecard. Jakarta: PT Gramedia Pustaka Utama

United Nations Educational, Scientific and Cultural Organization. (2009). Intangible Cultural Heritage: Indonesian Batik, [Online], ich.unnesco.org

Widiawati, D., Rosandini S.M. (2012). Natural Dyes on Indonesian Traditional Textiles-A Case Study: Geringsing Woven Fabric, In Tenganan Pegeringsingan Village Bali. The Research Journal of the Costume Culture, 20(1), 111-120.

Yuksel, I., Dagdeviren, M. (2007). Using the analytic network process (ANP) in a SWOT analysis-A case study for a textile firm, Information Sciences, 177, 3364-3382 